\title{
Bager
}

\section{Ilulissat Isfjord - et verdensarvsområde}

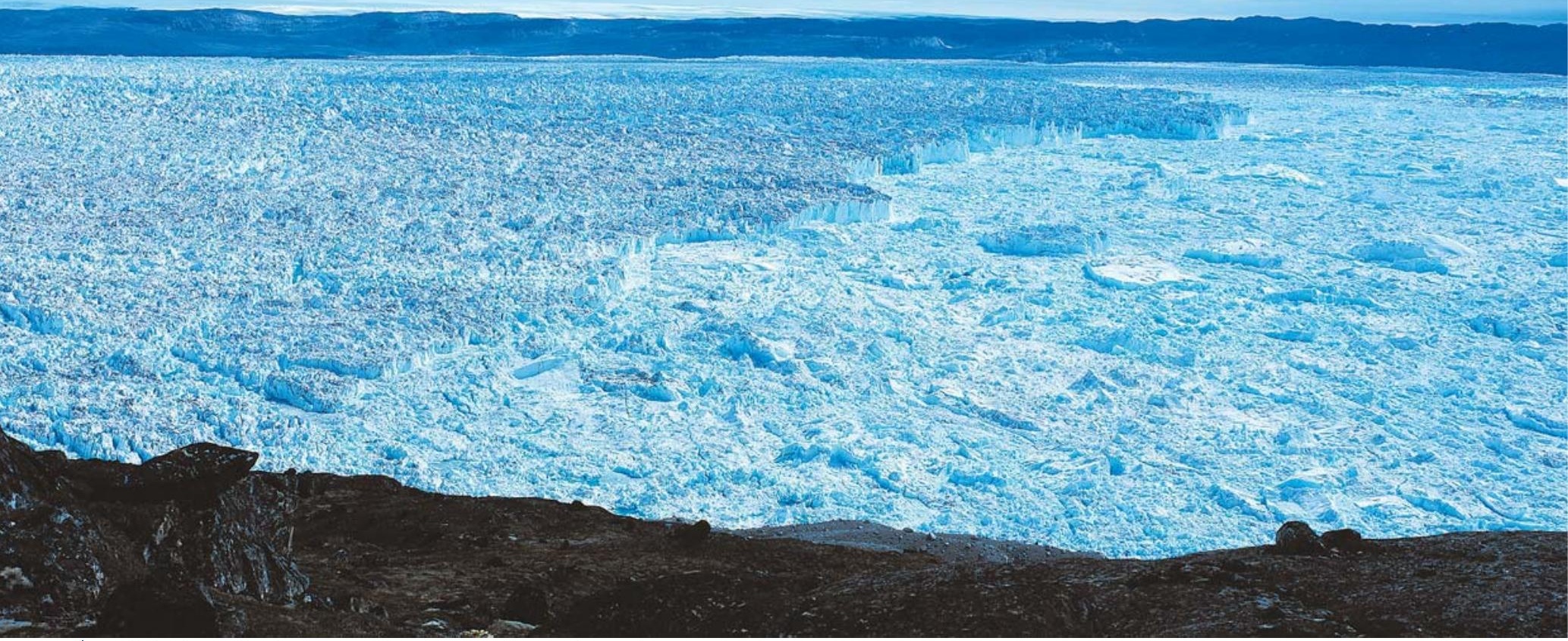

Billedet forestiller brcekanten af Sermeq Kujalleq set fra nord. (Foto: Jakob Lautrup, GEUS)

Anmeldt af Ulla V. Hjuler, GeologiskNyt

I slutningen af september udkom bogen Ilulissat Isfjord, der er udarbejdet af Danmarks og Grønlands Geologiske Undersøgelser (GEUS). Årsagen er, at Ilulissat Isfjord er blevet optaget på verdensarvslisten. Den flotte bog viser hvorfor.

I sommeren 2004 blev det af "The World Heritage Committee" vedtaget at optage Ilulissat Isfjord på verdensarvslisten. Listen blev oprettet i 1972 af UNESCO og har til formål at beskytte verdens kultur- og naturarv mod ødelæggelse, så vore efterkommere også kan få glæde af dem. Dermed kommer den i fint selskab med bl.a. Niagara Falls og Yellowstone Nationalparken i USA og den Kinesiske Mur. Der er nu optaget 788 områder fra i alt 134 lande på listen; 611 lokaliteter med kulturarv (i Danmark findes tre: Kronborg, Roskilde Domkirke, Runestenene ved Jelling) og 154 med naturarv - resten er blandede.

\section{Bogens opbygning}

Bogen er inddelt i forskellige afsnit, der i hovedtræk beskriver indlandsisen og relateret geologi, dyre- og planteliv samt isfjordens historie og lidt om fangst.

Den storslåede fjord ligger ved Diskobugten, dvs. på Grønlands vestkyst og omfatter ud over selve isfjorden - tilgrænsende landområder, en del af indlandsisen og isfjeldsbanken.

Ilulisat er Grønlands 3. største by med 4.400 indbyggere. Fiskeri og arbejdet på fiskefabrikken, som er Grønlands største, er byens vigtigste erhverv.

\section{Historien}

Det såkaldte Saqqaqfolk bosatte sig i nærheden af Ilulissat for ca. 4.400 år siden dvs. i stenalderen, men forsvandt igen efter 1.500 års bosættelse - derefter boede Dorsetfolket ved isfjorden fra for ca. 2.800 år siden og frem til Kristi fødsel. De næste 1.000 år var der ingen mennesker i området. For 800 år siden bosatte Thulefolket sig ved Sermermiut og Qajaa.

Bopladserne efter stenalderfolkene, der levede af jagt og fiskeri, viser, at der var rigeligt med stabile ressourcer. Thulefolket, der ankom til området ca. år 1200, fangede hvaler og var mere mobile end forgængerne med avancerede kajakker og hundeslæder. Folket havde kontakt med Nordboerene fra Island og Sydvestgrønland omkring år 985 . Efter den danske kolonisation i Nuuk i 1721 blev kontakten til europæerne mere stabil.

Hændelser som Englandskrigen (18071814) kunne mærkes i form af begrænsede forsyninger fra Danmark, og en tuberkuloseepidimi omkring 1867 bevirkede, at en del indbyggere i Ilulissat bukkede under.

Anden Verdenskrig blev en generel "opgangsperiode" for Grønland som helhed, da der oprettedes en direkte diplomatisk forbindelse til USA, hvilket medførte introducerede moderne forbrugsgoder. Her blev der 
også anlagt baser.

I forbindelse med det store lovkompleks, Nyorningen i 1950 blev Grønland en fuldgyldig del af Danmark, og herefter satte en rivende teknologisk udvikling i gang med bl.a. effektiv infrastruktur og moderne faciliteter til følge.

I 1979 blev Grønland en selvstændig del af Rigsfællesskabet efter en folkeafstemning. Danmark yder dog fortsat bloktilskud til Grønland.

\section{Indlandsisen og isfjorden}

Grønlands samlede areal er 2,2 mio. $\mathrm{km}^{2}$ ! Indlandsisen dækker et område på 1,7 mio. $\mathrm{km}^{3}$ (svarende til 2,9 mio. $\mathrm{m}^{3}$ is), og inde på midten måler den ca. $3,2 \mathrm{~km}$ i tykkelse. Indlandsisen drænes primært mod vest $i$ Diskobugten, da den i de sydlige og østlige dele er afgrænset af store bjergkæder. Isstrømmen, Sermeq Kujalleq (foto til venstre), der har udløb i området, er en af verdens hurtigste med 19 meter i døgnet, og den giver dermed ophav til $1 / 10$ af produktionen af alle isfjelde fra Indlandsisen.

Bogen giver en kort, spændende indføring i den historiske udforskning af Indlandsisen, gletschere, gletscherfronter. Desuden bliver læseren gjort bekendt medbegreber som galoperende gletschere, kalvning, dræningskanaler og meget mere - alt sammen kombineret med illustrative kort, bokse og tabeller og ikke mindst - flotte fotos.

Forskellige grafer illustrerer klimavariationer gennem de sidste 250.000 år vha iltisotoper, og undersøgelser af små luftbobler i isen fortæller om atmosfærens tidligere sammensætning. Det er Nord-GRIP-projektet med iskerneboringen, der går $3.085 \mathrm{~m}$ ned, som giver forskerne de fantastiske data.

Om tidligere nedisninger kan man ud fra borekerner fra havbunden bl.a. læse, at der

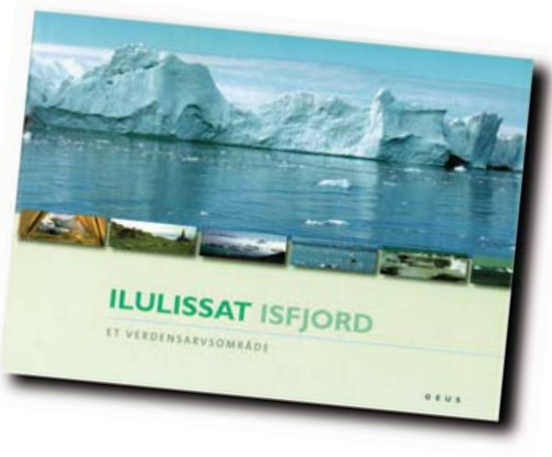

formentlig har fundet en markant global afkøling sted for 38-24 mio. år siden. Dette meførte dannelsen af det gigantiske isdække i Østantarktis. Herefter fulgte perioder med skiftende kolde og varme perioder.

Ved Kap København Formationen findes det tidligste tegn på en ny isfri periode. Formationen ligger i den nordligste del af Grønland, og for 2,4 mio. år siden mener man, at Grønland ikke var dækket af is. Der har således været områder med hedelandskab, nåleskove og løvfældende træer. Indlandsisen skulle først være dannet under de istider, vi kender, inden for den senste million år.

\section{Flora og fauna}

Dyre- og plantelivet hænger nøje sammen med is, smeltvand fra gletschere og isfjelde ved mundingen. Ved isens smeltning bringes det lettere, varmere og næringsrigere vand op til overfladen. Der produceres derfor store mængder plankton, og derfor tiltrækkes krebsdyr, fisk, sæler fugle mv. Hellefisken er den mest udbredte fiskeart ved udmundingen, og ringsælen lever der hele året.

På land finder man rensdyr, sneharer og polarræve. Atter er teksten ledsaget af forklarende figurer og smukke fotos af forskellige planter og dyr.
Bogen slutter af med lidt generel information om fangst, fx fritidsfangst og professionel fangst

\section{Utroligt flot bog}

En bog der virkeligt er informativ og bred $i$ sit indhold-geologi, biologi, smuk natur, kultur og historie - alle disse aspekter formår forfatterne at beskrive, og disse ledsages af gode forklarende bokse og flotte grafiske illustrationer. Men det er selvfølgelig de smukke billederne, man henføres over. Når man har set bogen, forstår man godt, hvorfor Ilulissat er kommet med på verdensarvslisten. Denne bog kan varmt anbefales, og den er et fremragende eksempel på, at geologi egner sig fremragende til formidling!

Ilulissat Isfjord - Et verdensarvsområde af Ole Bennike, Naja Mikkelsen, Henrik $K$. Pedersen og Anker Weidick med fotografier af Jakob Lautrup, alle GEUS, 116 sider - rigt illustreret. Bogen koster $324 \mathrm{kr}$. inkl. moms (men ekskl. forsendelse), og den kan købes hos GEUS eller Geografforlaget. Bogen findes tillige $i$ en engelsk og en grønlandsk udgave. ISBN: 87-7871-134-7.

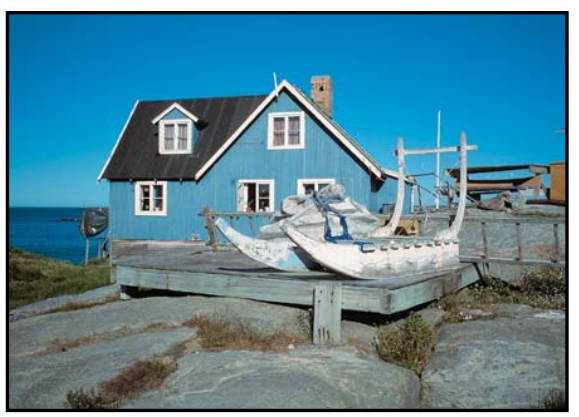

Stemningsbillede fra Ilulissat. (Foto: Jakob Lautrup, GEUS

\section{Kort nyt}

\section{Isfri Arktis i 2070?}

De seneste 30 år er den arktiske iskappes størrelse blevet formindsket med mellem 15 og $20 \%$, og en omfattende undersøgelse peger i retning af, at denne afsmeltningsrate vil accelerere til det dobbelte i fremtiden, således at det arktiske område vil være isfrit i 2070 .

Der har gennem tiden været nogle historiske forandringer i klimaet, som var udslag af naturlige processer, men ovennævite forandringer menes hovedsageligt at bunde $i$ en menneskeskabt tilvækst af drivhusgasser i atmosfæren.

Iskappernes afsmeltning vil få fatale konsekvenser for dyreliv, økonomiske aktiviteter og for menneskeheden som helhed, idet store områder vil blive oversvømmede og true lavtliggende millionbyer. Der forudses imidlertid også kortsigtede fordele, som at for eksempel visse olie- og gasreservoirer vil blive lettere tilgængelige, og at dyrkning af landbrugsjord vil blive mulig i mange regioner, hvor det er umuligt $i$ dag.

Nogle steder har man allerede fået en forsmag på, hvad klimaforandringer i fremtiden kan bringe. Eksempler er fangerne i det nordlige Grønland, der ikke har stabil havis at jage på i så mange måneder af året som tidligere, og permafrost der tør og gør bygninger ustabile.

Guardian Newpapers Limited/SP 